\title{
Characteristics of $S e^{\prime} i$ (Rotenesse Smoked Meat) Treated with Coconut Shell Liquid Smoked and Citrus aurantifolia Extract
}

\author{
G. E. M. Malelak*, G. M. Sipahelut, I. G. N. Jelantik, M. R. D. Ratu, \& H. J. D. Lalel \\ Department of Animal Science, Nusa Cendana University \\ Jalan Adisucipto Penfui, Kupang 85001, Nusa Tenggara Timur, Indonesia \\ (Received 08-01-2015; Reviewed 23-03-2015; Accepted 05-06-2015)
}

\begin{abstract}
The objective of this study was to investigate the effect of Citrus aurantifolia extract (CAE), coconut shell liquid smoke (CSLS) and the combination of CAE and CSLS (CACS) on se' $i$ characteristics. A completely randomized design was assigned in this experiment. Treatments used were: $s e^{\prime} i$ treated with $5 \%(\mathrm{v} / \mathrm{v})$ CAE, CSLS $5 \%(\mathrm{v} / \mathrm{v})$, (CAE : CSL 1:1) )/ (CACS) and untreated $s e^{\prime} i$ as a control (C). Parameters measured were: aroma, color, taste, $\mathrm{pH}$, residual nitrite, total bacterial count, Coliform, Staphylococcus aureus, Escherichia coli, and Salmonella. The data of aroma, color, and taste were analyzed by using Kruskal-Wallis test followed by Mann-Whitney test. The $\mathrm{pH}$, residual nitrite, and bacterial data were analyzed with analysis of variance (ANOVA) followed by least significant differences test. Results showed that CAE caused the highest score at both aroma and taste $(\mathrm{P}<0.05)$. CSLS caused the lowest residual nitrite $(27 \mathrm{ppm})(\mathrm{P}<0.05)$. Application of CAE and CACS could reduce total bacteria $(\mathrm{P}<0.05)$ at least 1 log. Color, $\mathrm{pH}$, and Coliform number were not significantly different. S. aureus, E. coli, and Salmonella were negative in all se'i samples. CAE gives the best organoleptics and bacteriological characteristics while CSLS is more effective in reducing nitrite.
\end{abstract}

Key words: Citrus aurantifolia extract, coconut shell liquid smoke, se'i, smoked beef

\section{ABSTRAK}

Tujuan penelitian ialah untuk menguji pengaruh penggunaan ekstrak jeruk nipis (Citrus aurantifolia) (EJN), asap cair tempurung kelapa (ACTK), dan gabungan pemberian EJN dan ACTK (EJTK) terhadap karakteristik daging $s e^{\prime} i$ (daging asap Rote). Penelitian ini menggunakan rancangan acak lengkap (RAL) dengan 4 perlakuan, yaitu $s e^{\prime} i$ yang tidak mendapat perlakuan sebagai kontrol, se'i yang diberi EJN $5 \%(\mathrm{v} / \mathrm{v})$, se'i yang diberi ACTK $5 \%(\mathrm{v} / \mathrm{v})$, dan $s e^{\prime} i$ yang diberi EJTK (EJN:ACTK 1:1). Setelah daging se'i dicampur dengan garam dan sendawa $\left(\mathrm{KNO}_{3}\right)$, se'i diberi EJN, ACTK, dan EJTK sesuai perlakuan yang disebut di atas. Campuran tersebut diperam sekitar 12 jam kemudian diasapi. Peubah yang diukur ialah aroma, warna, rasa, $\mathrm{pH}$, residu nitrit, total bakteri, Coliform, Staphylococcus aureus, Escherichia coli, dan Salmonella. Data aroma, warna, dan rasa dianalisis menggunakan analisis nonparametrik Kruskal-Wallis dilanjutkan dengan uji MannWhitney. Data $\mathrm{pH}$, residu nitrit, dan bakteria dianalisis menggunakan analisis varians (ANOVA) dan uji beda nyata terkecil (BNT). Hasil penelitian ini menunjukkan bahwa skor aroma dan rasa tertinggi adalah pada $s e^{\prime} i$ yang diberi $\mathrm{EJN}(\mathrm{P}<0,05)$. Residu nitrit terendah $(27 \mathrm{ppm})$ pada $s e^{\prime} i$ yang diberi ACTK. Pemberian EJN dan EJTK menyebabkan penurunan total bakteri $(P<0,05)$ sedikitnya 1 log. Skor warna, nilai $\mathrm{pH}$, dan jumlah bakteri Coliform pada semua sampel se' $i$ tidak berbeda dan berada pada standar normal kualitas daging se'i. S. aureus, E. coli, dan Salmonella terdeteksi negatif pada semua sampel $s e^{\prime} i$. Penelitian ini menyimpulkan bahwa pemberian EJN meningkatkan skor organoleptik dan menurunkan total bakteri. Perlakuan ACTK lebih efektif menurunkan residu nitrit pada daging $s e^{\prime} i$.

Kata kunci: ekstrak jeruk nipis, asap cair tempurung kelapa, se'i, daging asap

*Corresponding author:

E-mail: geminimalelak@yahoo.com.au 


\section{INTRODUCTION}

$S e^{\prime} i$ is a Rotenese traditional processed readyto-eat smoked meat product. Rote is a small island located in the west part of Indonesia that is in border with Australia. $S e^{\prime} i$ is made from boneless beef, pork, or deer meat. $S e^{\prime} i$ processing is begun with the meat is sliced into pieces with $\pm 3 \mathrm{~cm}$ of thickness from one side to other side of the meat so it has the rope- shape. The meat is spiced with salt and saltpeter $\left(\mathrm{KNO}_{3}\right)$ and then cured for $\pm 12 \mathrm{~h}$. The rope-shape meat was then arranged above the fire place for smoking until well done.

As a traditional product, se'i has a good prospect for culinary marketing in the future. However, recently quality of $s e^{\prime} i$ as smoked meat gets seriously attention because of the growing concern among consumers about such carcinogenic components which always contain in smoked meat. When the meat is placed directly upon the frame to be smoked, all components in smoke vapor will adhere directly to the meat surface. Meanwhile in the smoke contains both desirable and undesirable components. Undesirable components such as tars and polycyclic aromatic hydrocarbons (PAH) are recognized as being carcinogens. Moreover using wood as a fuel in smoking processing is quite difficult since it takes time and result of organoleptic characteristic is vary. First grade of liquid smoke, on the other hand, have some advantages such as easy to be applied, uniformity of the product, and the smoke products more clean. In coconut shell liquid smoke, components which are recognized as being carcinogens and always found in gas smoke, such as tars and polycyclic aromatic hydrocarbons (PAH), are not found (Budijanto et al., 2008).

The traditional (vaporous) smoking of $s e^{\prime} i$ is usually done by Schleichera oleosa wood smoke and above the meat surface is covered with $S$. oleosa raw leafs. Nowadays $S$. oleosa tree has been prohibited to be cut since the habitat of the tree almost extinct. Other wood smokes that could be used to smoke se' $i$ is coconut shell. However, it causes bitter in taste since the heat of coconut shell is too strong, thus application of coconut shell liquid smoke is prefer.

Several studies of the effect of liquid smoke were applied in several kinds of foods in the world such as color preservatives in raw tuna and salmon fish (Schubring, 2008), suppressed the growth of Listeria monocytogenes $(\mathrm{Lm})$ for up to $130 \mathrm{~d}$ in frankfurters (Martin et al., 2010), reduced TBA numbers, aroma score and $\mathrm{pH}$ values in ground beef (Estrada-Munoz et al., 2008), increased aroma score in beef (Arizona et al., 2011), prolong shelf life of fish ball (Zuraida et al., 2011), stabilized oxidation of catfish sausage (Ernawati et al., 2012), and decreased cut off strength of broiler meat (Yosi \& Sandi, 2014). Liquid smoke was also effective against various types of spoilage and pathogenic microorganisms (Milly et al., 2005).

Application of liquid smoke in meat can be used as a single treatment or is mixed with citric or acetic acids (Pearson \& Gillett, 1996). The combination of liquid smoke and citric acid give double benefits of the liquid smoke and the acid when be applied to se'i. Since price of liquid smoke is expensive while source of acids could be obtained from fresh citrus fruits that means is cheaper.

Using of Citrus aurantifolia could reduce lactic acid bacteria and Listeria in beef processing (FernandezLopez et al., 2005), increased meltability and elasticity of Mozzarella cheese (Purwadi, 2007), reduced residual nitrate level in cured meat (Ermawati, 2008) and increased level of water, carbohydrate and protein in cooked rice (Haq et al., 2010). Thus, addition of C. aurantifolia extract probably could change sensory attributes of $s e^{\prime} i$.

Traditionally, kinds of nitrate salt added in $s e^{\prime} i$ (smoke beef) processing is $\mathrm{KNO}_{3}$. Nitrate could result in formation of carcinogenic n-nitrosamines in cured meat, thus $C$. aurantifolia ability to reduce residual nitrite level could avoid the formation of nitrosamines and nitrosamides (Viuda-Martos et al., 2009). Organoleptics aspect, bacterial number, and residual nitrite in $s e^{\prime} i$ given liquid smoke or C. aurantifolia extract has not been reported yet.

The aim of this study was to compare the effect of coconut shell liquid smoke, C. aurantifolia extract, and their combination on organoleptic characteristics, $\mathrm{pH}$ value, residual nitrite, and antibacterial activity of $s e^{\prime} i$ (Rotenese smoked beef).

\section{MATERIALS AND METHODS}

A total of $22 \mathrm{kgs}$ of beef was obtained from butt and rump of Bali cattle bought in meat shop in Kupang. Coconut shell liquid smoke (CSLS) was obtained from Department of Technology Agriculture, Gadjah Mada University. The fruits of C. aurantifolia were washed with distilled water, sliced around from the top to the bottom and then squeezed to obtain the extract. To obtain $5 \%(\mathrm{v} / \mathrm{v})$ concentration of the extract or the liquid smoke, $5 \mathrm{~mL}$ of the extract or the liquid smoke were poured into $350 \mathrm{~mL}$ volumetric glass and then added distilled water to bring the volume to about $100 \mathrm{~mL}$. The mixture was heated at $45{ }^{\circ} \mathrm{C}$ in a stirring hot plate for 30 min, filtered with Whatman (No. 41) filter paper. Then stored at $4{ }^{\circ} \mathrm{C}$ for $2 \mathrm{~d}$ (until used).

\section{Treatments and $S e^{\prime} i$ Processing}

Completely randomized design (CRD) with 4 treatments was assigned in this experiment. Beef were trimmed off excessive of connective tissue and fat, sliced in rope-shape (lalolak). For each $\mathrm{kg}$ of beef, $500 \mathrm{mg}$ of saltpeter $\left(\mathrm{KNO}_{3}\right)$ and $2 \%$ of salt were added and mixed well manually. Total of $22 \mathrm{kgs}$ of the beef were divided into four groups as treatment given. The first group was untreated $s e^{\prime} i$ as control (C). The second group was subjected to $5 \%(\mathrm{v} / \mathrm{v})$ of coconut shell liquid smoke (CSLS), the third group was treated with $5 \%(\mathrm{v} / \mathrm{v})$ of C. aurantifolia extract (CAE), and the fourth group was added $5 \%$ $(\mathrm{v} / \mathrm{v})$ of coconut shell liquid smoke $+5 \%(\mathrm{v} / \mathrm{v})$ of juice of $C$. aurantifolia (CACS). Each group of beef was mixed well and marinated for $\pm 12 \mathrm{~h}$.

The marinated beef from the first group (C) and the third group (CAE), without liquid smoke, were smoked traditionally. While the second (CSLS) and the fourth group (CACS), treated with liquid smoke, were 
smoked in oven by using Hock stove with 22 wicks. All meat surface was covered with $S$. oleosa leaf while smoking, following the way of traditional se' $i$ processing. Then se'i was placed into polyethylene plastic bags, vacuumed with house-hold vacuum sealer Dhromex, and stored at cold temperature $\left(4^{\circ} \mathrm{C}\right)$ for $4 \mathrm{~d}$. At the fifth day, the packages were analysed.

$S e^{\prime} i$ analysis included organoleptic aspects: taste, aroma, and color. Other parameters measured were $\mathrm{pH}$, residual nitrite, and the bacterial numbers: total bacteria, coliform, Escherichia coli, Staphylococcus aureus, and Salmonella.

\section{Sensory Analysis}

A nine members of trained panelists from Animal Science Faculty students were selected for sensory analysis (color and aroma). At training time, these panelists were given 5 pieces of high-quality commercial $s e^{\prime} i$ taken from local market to familiarize the panelists about color and aroma of se'i products.

At evaluation time, each panelist was given four uncoded se'i samples and asked to evaluate the taste, aroma, and color. Panelists evaluated sensory attributes twice for each replicate. Evaluation was initiated after the panelists agreed on the specifications. The samples were served to each panelist separately. Panelists were asked to clean their palates between samples with water. The color and aroma were examined by using scoring test. The color score was: $5=$ very bright red color; $4=$ bright red color (specific se'i color), $3=$ dark red, $2=$ moderately dark red, $1=$ light red. To examine the aroma $30 \mathrm{~g}$ of samples were sliced, put into small glass jars, and allowed to stand for several hours (Bensink et al., 1973). On opening the jars, the panelists immediately examined the aroma by assigning score $1=$ no aroma to $5=$ very strong aroma.

The panelists were asked to examine the organoleptics (taste) on the score sheet for hedonic-scale rating test. The taste score was $5=$ like very much, $4=$ like moderately, $3=$ like slightly, $2=$ dislike moderately a $1=$ dislike very much. For each treatment, each penelist had three pieces of $s e^{\prime} i$ to be evaluated. An average of the three measurements to calculate mean score for each of the color, aroma, and taste of $s e^{\prime} i$ sample.

\section{Determination of $\mathrm{pH}$}

Determination of $\mathrm{pH}$ value was measured by using a Hanna digital $\mathrm{pH}$-meter at ambient temperature. A 10 $\mathrm{g}$ of $s e^{\prime} i$ was minced and then homogenized with $10 \mathrm{~mL}$ distilled water and filtered (with Whatman paper no 4). The $\mathrm{pH}$ meter was standardized between $\mathrm{pH} 4.0$ and 7.0. The filtrate $\mathrm{pH}$ obtained was recorded by inserting the probe of the $\mathrm{pH}$ meter into the filtrate for $30 \mathrm{~s}$ then the value was read. For each treatment, measurements were made in triplicate.

\section{Residual Nitrite Analysis}

Residual nitrate level of $s e^{\prime} i$ was determined as $\mathrm{mg}$ $\mathrm{NaNO}_{2} \mathrm{~kg}^{-1}$ meat by a spectrophotometer method at 540 nm as described in AOAC (1995). For each treatment, measurements were made in duplicate.

Around $5 \mathrm{~g}$ of $s e^{\prime} I$ was weighed, minced and transferred into a $250-\mathrm{mL}$ beaker. Forty milliliter of water was added and heated to $80{ }^{\circ} \mathrm{C}$ for $15 \mathrm{~min}$ then the mixture was transferred into a $250-\mathrm{mL}$ volumetric flask. Hot water was added to bring the volume to about 200 $\mathrm{mL}$ and the flask was transferred to steam bath for $2 \mathrm{~h}$ shaking occasionally. The solution was cooled to room temperature. The volume was completed to $250 \mathrm{~mL}$ with water, filtered, and centrifuged to clear the solution. Two and a half milliliters of sulphanilamide solution was added to aliquot containing 5-50 ug $\mathrm{NaNO}_{2}$ in 50 $\mathrm{mL}$ vol flask and the the solution was mixed. Two and a half milliliters of NED reagent was added and $5 \mathrm{~min}$ later, the solution was mixed and the colour was allowed to develop for $15 \mathrm{~min}$. A 5-mL portion of solution was transferred to photometer cell and absorbance was determined at $540 \mathrm{~nm}$ against blank of $45 \mathrm{~mL}$ water and $2.5 \mathrm{~mL}$ of sulphanilamide reagent, and $2.5 \mathrm{~mL}$ of NED reagent. The concentration of nitrite was determined by comparison with standard curve with straight line up to 1 ppm $\mathrm{NaNO}_{2}$ in final solution. To make standard curve; $10,20,30$, and $40 \mathrm{~mL}$ of nitrite working solution were added to $50 \mathrm{~mL}$ vol flasks. Two and a half milliliters of sulphanilamide reagent was added and after $5 \mathrm{~min}, 2.5$ $\mathrm{mL}$ of NED reagent was added.

\section{Bacterial Analysis}

Bacterial analysis were carried out following the procedure of Harrigan and McCance (1976). In each case, $10 \mathrm{~g}$ of each sample for microbiological evaluation were aseptically transferred into $90 \mathrm{~mL}$ of $0.1 \%$ sterile peptone water, shaken thoroughly and appropriate dilutions (up to $10^{5}$ ). Total viable counts (aerobic mesophiles) were made on Plate Count Agar (PCA, Oxoid, U.K.). Coliforms were isolated by using MacConkey broth and Eosin Methylene Blue agar. A 10-1 dilution of each sample was enriched in tetrathionate broth (Difco), incubated at $37{ }^{\circ} \mathrm{C}$ for $6 \mathrm{~h}$ before inoculation on Salmonella-Shigella agar (Oxoid) for isolation of Salmonellae. Typical colonies of Coliform were identified as round, red to pink, $0.5-2 \mathrm{~mm}$ in diameter, surrounded with a red to pink halo. Staphylococcus strains were isolated on Mannitol salt agar and Baird-Parker medium for S. aureus, incubated at $37{ }^{\circ} \mathrm{C}$ for 24 to $48 \mathrm{~h}$ (Elliot et al., 1978). All typical colonies on Baird-Parker agar were counted. The coagulase and catalase tests were used to differentiate $S$. aureus from other Staphylococci. For each treatment, measurements were made in triplicate.

\section{Statistical Analysis}

The data of color and aroma were analyzed by using non parametric, Kreskas-Wallis test. Mann-Whitney test was used to test for difference between means (significance $\mathrm{P}<0.05$; highly significant was $\mathrm{P}<0.01$ ). The $\mathrm{pH}$, residual nitrite, and bacterial data were analysed with analysis of variance (ANOVA). Least significant differences test was used to determine the differences 
among means (significantly different was $\mathrm{P}<0.05$; highly significant was $\mathrm{P}<0.01$ ) (SPSS, 18).

\section{RESULTS AND DISCUSSION}

\section{Sensory Characteristics}

The taste and aroma of $s e^{\prime} i$ that had treatments were significantly different from control se'i $(\mathrm{P}<0.05)$, however color was not significantly different from $s e^{\prime} i$ control $(\mathrm{P}>0.05)$. Table 1 showed that CAE caused the highest score at both taste and aroma of se'i samples while the control had the lowest score.

The juice of $C$. aurantifolia was squeezed from the fruit contained the most citric acid $(46 \mathrm{~g} / \mathrm{L}$ ) (Penniston et al., 2008). Citirc acid had sour in taste. Giving CAE caused se' $i$ has little sour in taste and panelists preferred to the taste compared to other se'i products in this experiment.

Budijanto et al. (2008) reported that the two main compounds contain in CSLS were guaiacol and its derivatives (36.58\%) and phenol and its derivatives (24.11\%). According to Varlet et al. (2007a) the phenol and guaiacol were mainly associated with aroma and flavour of smoked products. It was indicated that in this experiment the two compounds had a little influence in taste and aroma of se'i compared to citric acid in the CAE, eventhough CSLS caused higher score compared to control.

Color intensity in smoking product mainly depend on carbonyl-containing compounds that reacts with amino acids to form golden-brown color of smoked products, Maillard - type reaction (Varlet et al., 2007b). In CSLS contained carbonyls and acids (2.98\%) (Budijanto et al., 2008). While in CAE commonly contain ascorbic acid, malic acid, and citric acid. Ascorbic acid in CAE can accelerate the conversion of nitrite to nitric oxide (NO) thus could promote cured color formation (Gøtterup et al., 2008).

In cured meat, when nitrate was given, it was converted to nitrite by nitrate - reducing bacteria and then nitrite was reduced to nitric oxide (NO) that reacted with myoglobin to form nitric-oxymyoglobin, red in color but unstable. When the meat was smoked, nitric-oxymyoglobin was converted to Nitrosylhemochromagen that was responsible for stable cured-pink color (Sebranek \& Bacus, 2007) that was a specific color of se'i. Table 1 revealed that there was no significant difference between treated samples, and all the color score was

Tabel 1. Score of taste, aroma, and color of se'i treated with coconut shell liquid smoke (CSLS), Citrus aurantifolia extract (CAE), and combination of coconut shell liquid smoke and C. aurantifolia extract (CACS)

\begin{tabular}{lcccc}
\hline Treatment & Control & CSLS & CAE & CACS \\
\hline Taste & $3.90 \pm 0.01^{\mathrm{a}}$ & $4.30 \pm 0.02^{\mathrm{b}}$ & $4.70 \pm 0.01^{\mathrm{c}}$ & $4.10 \pm 0.02^{\mathrm{b}}$ \\
Aroma & $3.60 \pm 0.01^{\mathrm{a}}$ & $3.90 \pm 0.02^{\mathrm{b}}$ & $4.70 \pm 0.01^{\mathrm{c}}$ & $4.20 \pm 0.01^{\mathrm{b}}$ \\
Color & $3.28 \pm 0.02^{\mathrm{a}}$ & $4.32 \pm 0.01^{\mathrm{a}}$ & $4.20 \pm 0.02^{\mathrm{a}}$ & $4.34 \pm 0.01^{\mathrm{a}}$ \\
\hline
\end{tabular}

Note: Means in the same row with different superscripts differ significantly $(\mathrm{P}<0.05)$ normal color of $s e^{\prime} i$. Although CSLS could reduce more nitrite in $s e^{\prime} i$ (Table 2), the same effect in se' $i$ indicated that carbonyls in CSLS and ascorbic acid in CAE had the same effect on $s e^{\prime} i$ color.

\section{pH Value}

Acids contained in substances can influence the $\mathrm{pH}$ value of se'i. CAE contains citric acid, malic acid, and ascorbic acid (Güçlü et al., 2005) whereas CSLS contains formic, acetic, propionic, and butyric acids (Pearson \& Gillet, 1996). Although that kind of organic acids contained in CAE and CSLS were different, addition of CAE, CSLS, and their combination could not alter the $\mathrm{pH}$ value of $s e^{\prime} i$ (Table 2). However, the $\mathrm{pH}$ values of $s e^{\prime} i$ samples were below the critical limit value of 7.0, which indicated the ability of CAE, CSLS, and CACS to inhibit or reduce the development of bacteria in $s e^{\prime} i$.

\section{Residual Nitrite}

In $s e^{\prime} i$ processing, nitrate/saltpeter added for the purpose of curing will be found in the finished product as residual nitrite. In this experiment, the residual nitrite levels (ppm) of se'i samples were shown in Table 2. Addition of CSLS, CAE, and CACS could reduce residual nitrate level in se'i compared to control $(\mathrm{P}<0.05)$ and the lowest residual found in $s e^{\prime} i$ sample treated with CSLS.

The means residual nitrite permitted in processing meat is $30 \mathrm{mg} / \mathrm{kg}$ (Indonesian Food and Drugs Board, 2013). In this experiment the only se' $i$ sample fixed to the rule was $s e^{\prime} i$ treated with CSLS. Level of nitrate used in this experiment was $500 \mathrm{mg} / \mathrm{kg}$ of beef. When nitrate was added to meat, this compound would be converted to nitrite and nitrite reacts with oxygen to form nitric oxide (NO). It is about 5\%-15\% NO bound with myoglobin, $5 \%-15 \%$ bound with sulfhydryl group, $1 \%-5 \%$ bound with lipid, and 20\%-30\% bound with protein. Thus the amount of nitrate left after processing only less than $50 \%$ (Cassens et al., 1976). In this experiment the amount of nitrate left range from $5.4 \%-85.4 \%$. Residual nitrite in se' $i$ could be decreased by reducing the initial nitrate level. In $s e^{\prime} i$ processing, potassium nitrate/saltpeter $\left(\mathrm{KNO}_{3}\right)$ is added as preservative and for color development. Nitrate could inhibit outgrowth and neurotoxin formation by C. botulinum (Yetim et al., 2006) and could help to form typical red or pink color of cured meat (Gøtterup et al., 2008). Various factors influence the

Tabel 2. $\mathrm{pH}$ value and residual nitrite (ppm) of se'i treated with coconut shell liquid smoke (CSLS), Citrus aurantifolia extract (CAE), and combination of coconut shell liquid smoke and C. aurantifolia extract (CACS)

\begin{tabular}{lrrrr}
\hline \multicolumn{1}{c}{ Treatment } & \multicolumn{1}{c}{ Control } & \multicolumn{1}{c}{ CSLS } & \multicolumn{1}{c}{ CAE } & \multicolumn{1}{c}{ CACS } \\
\hline $\mathrm{pH}$ & $5.63 \pm 0.01^{\mathrm{a}}$ & $5.59 \pm 0.03^{\mathrm{a}}$ & $5.50 \pm 0.03^{\mathrm{a}}$ & $5.63 \pm 0.01^{\mathrm{a}}$ \\
$\begin{array}{l}\text { Residual } \\
\text { nitrite }(\mathrm{ppm})\end{array}$ & $427.00 \pm 0.10^{\mathrm{a}}$ & $27.00 \pm 0.05^{\mathrm{b}}$ & $384.00 \pm 0.01^{\mathrm{c}}$ & $236.00 \pm 0.12^{\mathrm{d}}$ \\
\hline
\end{tabular}

Note: Means in the same row with different superscripts differ significantly $(\mathrm{P}<0.05)$. 
Table 3. The number of total bacteria, Coliform, Staphylococcus aureus, E. coli, and Salmonella $(\log \mathrm{cfu} / \mathrm{g} \pm \mathrm{SD})$ of se'i treated with coconut shell liquid smoke (CSLS), Citrus aurantifolia extract (CAE), and combination of coconut shell liquid smoke and C. aurantifolia extract (CACS)

\begin{tabular}{cccccc}
\hline Treatment & Total bacteria $(\mathrm{cfu})$ & Coliform $(\mathrm{mpn} / \mathrm{g})$ & Staphylococcus aureus & E. coli & Salmonella \\
\hline Control & $4.87 \pm 0.22^{\mathrm{a}}$ & $0.32 \pm 0.12$ & Negative & Negative & Negative \\
CSLS & $4.66 \pm 0.11^{\mathrm{a}}$ & $0.01 \pm 0.01$ & Negative & Negative & Negative \\
CAE & $3.48 \pm 0.12^{\mathrm{b}}$ & $0.56 \pm 0.01$ & Negative & Negative & Negative \\
CACS & $3.87 \pm 0.01^{\mathrm{b}}$ & $0.56 \pm 0.01$ & Negative & Negative & Negative \\
\hline
\end{tabular}

Note: Means in the same column with different superscripts differ significantly $(\mathrm{P}<0.05)$.

rate of nitrite reduction such as $\mathrm{pH}$, the presence of reductants, initial nitrate level (Pérez-Alvarez et al, 1993 in Viuda-Martos et al., 2009) heating process, and storage time (Sebranek \& Bacus, 2007). In this study, pH of all $s e^{\prime} i$ samples, initial nitrate level and storage time were same thus the effect of the three factors on reducing nitrite were neglected.

The lowest residual nitrite was reached when $s e^{\prime} i$ was treated with CSLS and when CSLS combine with CAE (CACS) the residual nitrite was lower than $s e^{\prime} i$ treated with CAE only. It is indicated that the role of reductants such as active biocompounds (polyphenols) (Moawad et al., 2012) presented in CSLS (Budijanto et $a l ., 2008)$ is more effective in reducing nitrite in $s e^{\prime} i$ compared to ascorbic acid present in CAE.

It is important to keep residual nitrite at low level to prohibit nitrosamine formation in $s e^{\prime} i$ product, since nitrosamine seems to be associated with gastric cancer (Jakszyn \& Gonzales, 2006; Larsson et al., 2006). Nitrosamines are formed when nitrite reacts with secondary amines in food.

\section{Bacterial Characteristic}

Bacterial numbers (total bacteria, coliform, S. aureus, E. coli, and Salmonella) of se'i samples were shown in Table 3. Maximum limitation of bacterial contamination permitted in smoked meat was $1 \times 10^{5} \mathrm{cfu}$ (5 log cfu/g) and $10 \mathrm{mpn}$ for Coliform (SNI.7388:2009). Comparing to the data in Table 3 it showed that there was no $s e^{\prime} i$ sample in all treatment and control having number of bacteria higher than $1 \times 10^{5} \mathrm{cfu}$. It is indicated that all $s e^{\prime} i$ samples exhibit good quality. S. aureus, E. coli, and Salmonella were not detected in se'i samples.

Application of $C$. aurantifolia (CAE), coconut shell liquid smoke $+C$. aurantifolia (CACS) could reduce the number of total bacteria $(\mathrm{P}<0.05)$ at least $1 \mathrm{log}$. It seemed that the effectiveness of coconut shell liquid smoke in reducing the total bacteria number increased when it mixed with $C$. aurantifolia extract (CAE), whereas Coliform bacteria was same in all se'i samples.

It was reported that phenolic, carbonyls, and organic acids compounds contained in liquid smoke had antibacterial activity (Pearson \& Gillet, 1996). However, the major contribution came from phenolic group such as phenol, 2-methoxylphenol (guaiacol), 3,4 dimethoxylphenols, and 2-methoxy-4-methyl phenol (Soldera et al., 2008). Meanwhile flavonoids and vitamin C are prominent in C. aurantifolia and play a major contribu- tion in antibacterial activity (Martin et al., 2002). Based on data of Table 3, it was obvious that C. aurantifolia had a stronger antibacterial activity compared to liquid smoke. Flavonoids and vitamin $C$ might enhance the effectiveness of phenols as antibacterial activity when CSLS and CAE applied together (CACS).

\section{CONCLUSION}

The taste, aroma, and bacterial characteristics of $s e^{\prime} i$ treated with $C$. aurantifolia extract (CAE) would appear to be better when treated with coconut shell liquid smoked (CSLS). Antibacterial effect of CSLS increased when combined with CAE (CACS). S. aureus, E. coli and Salmonella were not detected in all se'i samples. The color and $\mathrm{pH}$ of $s e^{\prime} i$ were not affected by treatments. CSLS was the best treatment in reducing nitrite in $s e^{\prime} i$.

\section{ACKNOWLEDGEMENT}

Authors thank to the Directorate General for Higher Education, the Ministry of National Education for funding support through "Hibah Bersaing" 20102011. Mr. Subandono is gratefully acknowledged for his technical help in producing the liquid smoke

\section{REFERENCES}

AOAC. 1995. Official Methods of Analysis. $16^{\text {th }}$ ed. Association of Official Analytical Chemists, Arlington, Virginia, USA.

Arizona, R., E. Suryanto, \& Y. Erwanto. 2011. The effect of canary shell liquid smoke concentration and storage time on chemical and physical quality of beef. Buletin Peternakan. 35: 50-56.

Bensink, J. C., A. L. Ford, \& J. R. Yates. 1973. Properties and performance at a range of commercial vacuum packaging films used for packing chilled beef. Meat Research Report. 4/73:1

Budijanto, S., R. Hasbullah, S. Prabawati, Setyadjit, Sukarno, \& I. Zuraida. 2008. Identifikasi dan uji keamanan asap cair tempurung kelapa untuk produk pangan.J.Pascapanen 5: 32-40.

Cassens, R.G., G. Woolford, S.H. Lee and R. Goutefon gea, 1976. Fate of nitrite. Meat Proceedings 2nd International Symposium of Nitrite in Meat Products , Zeist, Pudoc, Wageningen, Netherlands. Pp: 95-100.

Elliot, R. P., K. H. Clark., H. Lewis., J. C. Lundbeck., J. R. O1son, \& B. Simonsen. 1978. Microorganisms in Food 1. Their Significance and Methods of Enumeration, $2^{\text {nd }}$. ed. University of Toronto Press, Toronto.

Ernawati, H. Purnomo, \& T. Estiasih. 2012. Antioxidant effect of liquid smoke on oxidation stability of catfish (Clarias 
gariepinus) smoke sausage during storage. Jurnal Teknologi Pertanian 13: 119-124.

Ermawati, D. 2008. Pengaruh penggunaan ekstrat jeruk nipis (Citrus aurantifolia swingle) terhadap residu nitrit daging curing selama proses curing. http://digilib.uns.ac.id.(accessed August 22, 2009).

Estrada-Munoz, R., E. A. E. Boyle, \& J. L. Marsden. 2008. Liquid smoke effects on Escherichia coli 0157:H7, and its antioxidant properties in beef products. J. Food Sci. 63:150-153. http://dx.doi.org/10.1111/j.1365-2621.1998.tb15697.x

Fernandez-Lopez, J., N. Zhi, L. Aleson-Carbonell, J. A. PerezAlvarez, \& V. Kuri. 2005. Antioxidant and antibacterial activities of natural extracts: application in beef meatballs. Meat Sci. 69: 371-380. http://dx.doi.org/10.1016/j.meatsci.2004.08.004

Gøtterup J., K, Olsen, S. Knøchel., K. Tjener., L. H. Stahnke, \& J. K. S. Møller. 2008. Colour formation in fermented sausages by meat-associated staphylococci with different nitrite- and nitrate-reductase activities. Meat Sci. 78:492-501. http://dx.doi.org/10.1016/j.meatsci.2007.07.023

Güçlü, K., K. Sözgen, E. Tütem., M. Özyürek, \& R. Apak. 2005. Spectrophotometric determination of ascorbic acid using copper(II)-neocuproine reagent in beverages and pharmaceuticals. Talanta. 65:1226-1232. http://dx.doi.org/10.1016/j. talanta.2004.08.048

Haq, G. I., A. Permanasari, \& H. Sholihin. 2010. Effectivity of lime juice on cooked rice. Jurnal Sains dan Teknologi Kimia 1: 44-58.

Harrigan, W. F. \& M. E. McCance. 1976. Laboratory Methods in Food and Dairy Microbiology. Academic Press, London, U.K. p. 452.

Indonesian Food and Drugs Board. 2013. Indonesian Food and Drugs Board. Rule No. 36/2013. Maksimum level of using preservative ingredients.

Jakszyn, P. \& C. A. Gonzales. 2006. Nitrosamine and related food intake and gastric and oesophageal cancer risk: A systematic review of the epidemiological evidence. World J. Gastroenterol 12:4296-4303.

Larsson S, C., L. Bergkvist, \& A. Wolk. 2006. Processed meat consumption, dietary and stomach cancer risk in a cohort of Swedish women. Int. J. Cancer. 119:915-9. http://dx.doi. org/10.1002/ijc. 21925

Martín, F. R., M. J. Frutos, J. A. Pérez-Alvarez, F. MartínezSánchez, \& J. A. Del Río. 2002. Flavonoids as Nutraceuticals: Structural Related Antioxidant Properties and Their Role On Ascorbic Acid Preservation. In: Atta-Ur-Rahman (Ed.). Studies in Natural Products Chemistry. Vol. 26. Elsevier Science, Amsterdam. pp. 324-389

Martin, E. M., C. A. O'Bryan, R. Y. Lary Jr, C. L. Griffis, K. L. S. Vaughn, J. A. Marcy, S. C. Ricke, \& P. G. Crandal. 2010. Spray application of liquid smoke to reduce or eliminate Listeria monocytogenes surface inoculated on frankfurters. Meat Sci. 85:640-644. http://dx.doi.org/10.1016/j.meatsci.2010.03.017
Milly, P. J., R. T. Toledo, \& Ramakrishnan. 2005. Determination of minimum inhibitory concentrations of liquid smoke fractions. J. Food Sci. 70:12-17. http://dx.doi. org/10.1111/j.1365-2621.2005.tb09040.x

Moawad, R. K., W. M. Abozeid, \& A. S. Nadir. 2012. Effect of nitrite level and tea catechins on residual nitrite and quality indices of raw-cured sausages. J. Appl. Sci Res. 8: 815822.

Pearson, A. M. \& T. A. Gillett. 1996. Processed Meats. $3^{\text {rd }}$ ed. Chapman and Hall. USA.

Penniston, K. L., S. Y. Nakada, R. P. Holmes, \& D. G. Assimos. 2008. Quantitative assessment of citric acid in lemon juice, lime juice, and commercially-available fruit juice products. J. Endourol. 22: 567-570. http://dx.doi.org/10.1089/ end.2007.0304

Purwadi. 2007. Trial of lime juice on Mozzarella cheese. Jurnal Ilmu dan Teknologi Hasil Ternak. 2:28-34.

Schubring, R. 2008. Use of "filtered smoke" and carbon monoxide with fish. J.Cons.Prot. Food Safety. 3:31-44. http:// dx.doi.org/10.1007/s00003-007-0298-0

Sebranek, J. G. \& J. N. Bacus. 2007. Cured meat products without direct addition of nitrate or nitrite: what are the issues?. Meat Sci. 77:136-147. http://dx.doi.org/10.1016/j. meatsci.2007.03.025

Soldera, S., N. Sebastianutto, \& R. Bortolomeazzi. 2008. Composition of phenolic compounds and antioxidant activity of commercial aqueous smoke flavorings. J. Agric.Food Chem. 56: 2727-2734. http://dx.doi.org/10.1021/jf072117d

Varlet, V., C. Prost, \& T. Serot. 2007a. New procedure for the study of odour representativeness of aromatic extracts from smoked salmon. Food Chem. 100:820-829. http:// dx.doi.org/10.1016/j.foodchem.2005.09.019

Varlet V., C. Prost, \& T. Serot. 2007b. Volatile aldehydes in smoked fish: analysis methods, occurrence and mechanisms of formation. Food Chem. 105:1536-1556. http:// dx.doi.org/10.1016/j.foodchem.2007.03.041

Viuda-Martos, M., J. Fernández-López, E. Sayas-Barbera, E. Sendra, C. Navarro, \& J. A. Perez- Alvarez. 2009. Citrus co-products as technological strategy to reduce residual nitrate content in meat products. J. Food Sci. 74:93-100. http://dx.doi.org/10.1111/j.1750-3841.2009.01334.x

Yetim H., A. Kayacier., Z. Kesmen, \& O. Sagdic. 2006. The effects of nitrite on the survival ofClostridium sporogenesand the autoxidation properties of the kavurma. Meat Sci. 72:206-10. http://dx.doi.org/10.1016/j.meatsci.2005.07.002

Yosi, F. \& S. Sandi. 2014. Meat quality, blood profile, and fecal ammonia concentration of broiler supplemented with liquid smoke. Med. Pet. 37: 169-174. http://dx.doi.org/10.5398/ medpet.2014.37.3.169

Zuraida, I., Sukarno, \& S. Budijanto. 2011. Antibacterial activity of coconut shell liquid smoke (CS-LS) and its application on fish ball preservation. International Food Research Journal. 18:405-410. 